\title{
Do new ways of working increase work engagement?
}

Citation for published version (APA):

Gerards, R., de Grip, A., \& Baudewijns, C. (2018). Do new ways of working increase work engagement? Personnel Review, 47(2), 517-534. https://doi.org/10.1108/PR-02-2017-0050

Document status and date:

Published: 01/01/2018

DOI:

10.1108/PR-02-2017-0050

Document Version:

Publisher's PDF, also known as Version of record

Document license:

Taverne

\section{Please check the document version of this publication:}

- A submitted manuscript is the version of the article upon submission and before peer-review. There can be important differences between the submitted version and the official published version of record.

People interested in the research are advised to contact the author for the final version of the publication, or visit the DOI to the publisher's website.

- The final author version and the galley proof are versions of the publication after peer review.

- The final published version features the final layout of the paper including the volume, issue and page numbers.

Link to publication

\footnotetext{
General rights rights.

- You may freely distribute the URL identifying the publication in the public portal. please follow below link for the End User Agreement:

www.umlib.nl/taverne-license

Take down policy

If you believe that this document breaches copyright please contact us at:

repository@maastrichtuniversity.nl

providing details and we will investigate your claim.
}

Copyright and moral rights for the publications made accessible in the public portal are retained by the authors and/or other copyright owners and it is a condition of accessing publications that users recognise and abide by the legal requirements associated with these

- Users may download and print one copy of any publication from the public portal for the purpose of private study or research.

- You may not further distribute the material or use it for any profit-making activity or commercial gain

If the publication is distributed under the terms of Article $25 \mathrm{fa}$ of the Dutch Copyright Act, indicated by the "Taverne" license above, 


\title{
Do new ways of working increase work engagement?
}

\author{
Ruud Gerards, Andries de Grip and Claudia Baudewijns \\ Research Centre for Education and the Labour Market, Maastricht University, \\ Maastricht, The Netherlands
}

\begin{abstract}
Purpose - The purpose of this paper is to shed more light on the impact of the various facets of new ways of working (NWW) on employee work engagement, taking into account multiple sectors and occupational fields. Design/methodology/approach - Insights from the literature and the job demands-resources model underpin the hypotheses on how NWW would affect work engagement. The hypotheses were tested using the Preacher and Hayes' (2008) bootstrap method for multiple mediation and controls, taking into account two potential mediators between (facets of) NWW and work engagement: social interaction in the workplace and transformational leadership.

Findings - The analyses show that three facets of NWW - management of output, access to organizational knowledge, and a freely accessible open workplace - positively affect employees' work engagement. The latter two facets appear to be fully mediated by social interaction and transformational leadership.

Practical implications - The results imply that firms should foster transformational leadership styles among their line managers, and social interaction in the workplaces, to maximize the positive impact of NWW on work engagement.

Originality/value - This empirical paper draws on a unique data set on the Dutch working population to provide novel insights with a substantial degree of generalizability into the relation between NWW and work engagement, whilst applying a more comprehensive definition of NWW than previously applied, while incorporating two potential mediators.
\end{abstract}

Keywords Quantitative, Work engagement, New ways of working, Social interaction,

Transformational leadership (TL), Multiple mediation

Paper type Research paper

\section{Introduction}

Enabled by rapid advances in information and communications technology, human resource management practices associated with new ways of working (NWW) are a recent phenomenon that consists of a large variety of human resource management practices such as management of output, teleworking, and flexibility in time and location of work. However, there are few studies on the effects of NWW on employee outcomes and little is known about the impact of NWW on employee work engagement. Yet, there are some notable exceptions. Peters et al. (2014) relate NWW practices to work enjoyment, conceptualized as "work-related flow." In a Dutch study, Peters et al. (2013) conclude that NWW has the potential to increase work engagement through increased worker autonomy and access to teleworking, whereas Ten Brummelhuis et al. (2012) conclude that NWW has the potential to boost work engagement by increasing employee process control and facilitating more efficient communication among colleagues. However, the latter study is based on employees in a single firm, which leads the authors to recommend future research to study the generalizability of the relationship between NWW and work engagement.

The present paper answers their call and adds new insights to the emerging literature on the effects of NWW on work engagement. This paper makes four contributions to the

The authors thank Evert Webers, Roger Schils and Eric Schlösser of RMI/IBC for their assistance in the survey design, and Marion Collewet and Jol Stoffers for their helpful comments on an earlier version of this paper. The authors also thank participants of the 2015 International Conference of the Dutch HRM Network and the 2013 INSCOPE Annual Conference for their comments.

Received 17 February 2017 Revised 22 August 2017 6 October 2017

Accepted 28 October 2017

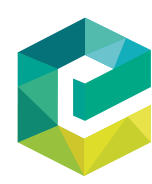

Personnel Review Vol. 47 No. 2, 2018 pp. $517-534$ (C) Emerald Publishing Limited 0048-3486 
PR

47,2

518

literature. First, we examine the impact of several facets of NWW on work engagement of employees in 12 occupational fields in all sectors of the Dutch economy. Here, we build on Peters et al. (2014), who investigate the impact of NWW on work-related flow in a few specific job categories across multiple organizations.

Second, current studies in the work engagement literature include only single facets or a less comprehensive bundle of NWW practices, such as increased levels of autonomy or management of output (Bakker and Bal, 2010), flexible work time and location, new media technologies (Ten Brummelhuis et al., 2012), or flexibility in working relations (Bal and De Lange, 2015). Building on this literature, we use a more comprehensive definition of NWW, including five facets of NWW[1]: time- and location-independent work, management of output, free accessibility and use of knowledge and ideas (access to organizational knowledge), flexibility in working relations, and freely accessible open workplace (Graham, 2004; Halford, 2005; Baane et al., 2010). We estimate models that distinguish the individual facets. These models enable us to disentangle in which positive or negative direction each facet of NWW contributes to the overall effect of NWW on work engagement.

Third, building on Kelley and Kelloway (2012), Ten Brummelhuis et al. (2012), and De Leede and Kraijenbrink (2014), we take account of two potential mediators between (facets of) NWW and work engagement: social interaction in the workplace and the extent to which management is characterized by transformational leadership. Although De Leede and Kraijenbrink (2014) acknowledge that leadership needs to be taken into account when studying the effects of NWW, and some authors even incorporate it into their analyses (e.g. Peters et al., 2014, who include "supportive leadership"), we are the first to consider "transformational leadership" as a mediator between NWW and work engagement.

Fourth, we add to the literature on the effects of human resource practices on work engagement. Despite a vast body of literature on work engagement, including many studies on the definition and foundations of the concept itself, as well as studies on its consequences or antecedents (e.g. Bakker et al., 2008; Rana et al., 2014), the relation between specific human resource management practices (such as the various facets of NWW) and work engagement has gained attention only more recently (Maden, 2015). Saks (2006) finds that employee engagement, which Schaufeli et al. (2002, p. 74) characterize as having a "positive, fulfilling, work-related state of mind characterized by vigor, dedication, and absorption," is enhanced by jobs that offer challenging work and variety, that allow for the use of a variety of skills and personal discretion, and that afford the opportunity to meaningfully contribute to the firm and/or society. Maden (2015) finds that empowerment increases employee work engagement. As shown in the next section, NWW includes several human resource management practices that may affect work engagement.

This paper proceeds as follows. The next section discusses the literature on the five facets of NWW we identify, along with social interaction at work and transformational leadership. From this literature, we derive our empirical model and hypotheses. The next section describes our data and variables of interest. This is followed by a section in which we present our estimation results. The final four sections summarize our findings and discuss the contributions, practical implications, and limitations of our paper and its recommendations for future research, respectively.

\section{Literature}

\section{$N W W$}

Several authors note that the scientific literature on NWW remains limited. De Leede and Kraijenbrink (2014) disentangle NWW into three facets: flexibility, working at home, and working together at a distance, whereas Peters et al. (2013) define NWW as a bundle of access to teleworking, worker autonomy, and management of output. Baane et al. (2010) disentangle NWW even further into four facets: time- and location-independent work, 
management of output, access to organizational knowledge, and flexibility in working relations. However, Baane et al. (2010) do not account for the interplay between the physical and mental work environments that is at the heart of NWW, as organizations that implement NWW often refurbish offices from traditional closed offices into open-office layouts. Building on Graham (2004) and Halford (2005), we therefore extend the four NWW facets of Baane et al. (2010) with a fifth facet labeled freely accessible open workplace. We now explain each of the five facets we distinguish.

The first NWW facet refers to working independent of time and place (Baane $e t$ al., 2010). Halford (2005, p. 26) illustrates this facet by quoting several phrases from an employee of a large UK-based financial services company: "Sometimes you think, 'Oh I really need to get this done, I'll go home' [...] so it's nice in a way that you have got somewhere you can go and work in quiet." The second NWW facet refers to management of output or performance rather than management of how employees conduct their work (Baane et al., 2010); this allows workers themselves to determine the way they work. The first two facets of NWW actually split up worker autonomy into a time and place facet and a way of working facet (Thompson and Prottas, 2006). The third NWW facet refers to free access to and use of organizational knowledge, experience, and ideas (Baane et al., 2010), meaning that workers can freely access organizational knowledge on their tablets, smartphones, or computers and reach their colleagues and managers quickly. Mura et al. (2012) find that this knowledge sharing is an essential mediator between intellectual capital and innovative work behavior as "a larger portion of the collective organizational intellectual capital is made available for and used by the individual employees" (Moll and De Leede, 2016, p. 97). The fourth NWW facet refers to practices that allow employees to accommodate their working life in such a way that it fits with their current private situation. Baane et al. (2010) describe this as a shift from "one size fits all" to flexibility in working relations. The fifth NWW facet is derived from the studies that emphasize the interplay between the physical and mental environments. Graham (2004) argues that employee behavior always depends to some extent on physical elements of the workplace. Organizations with NWW facets often refurbish offices into freely accessible open workplaces. These freely accessible workplaces are intended to minimize physical and mental distance via stimulating encounters and cooperation among colleagues[2]. Following Halford (2005), we label this fifth facet of NWW the "freely accessible open workplace." As the first three facets are also commonly encountered in the literature on flexible work design (FWD), teleworking or telecommuting[3], it is the inclusion of facets four (flexibility in working relations) and five (freely accessible open workplaces) that conceptually extends NWW beyond these other concepts.

Scholars have so far proposed different mechanisms through which NWW increases work engagement. According to Ten Brummelhuis et al. (2012), NWW has the potential to boost work engagement by increasing employee process control and fostering efficient communication among colleagues. Peters et al. (2013) also conclude that NWW has the potential to enhance work engagement, specifically through access to teleworking and worker autonomy. This is supported by the results from several other studies that find that worker autonomy is positively related to work engagement (Bakker and Bal, 2010). Bakker et al. (2011) propose that employees who manage their own work increase their job challenges and job resources and subsequently remain more engaged. Furthermore, Bal and De Lange (2015) find a positive relation between the fourth facet of NWW, flexibility in working relations (which they label as "flexibility human resource management"), and employee engagement.

Although most studies expect mainly positive impacts from NWW on work engagement, the question remains whether specific elements of NWW, such as time- and location-independent work, resulting in always being online and connected, may reduce work engagement (De Leede and Kraijenbrink, 2014). Sardeshmukh et al. (2012) find that
New ways of working 
PR

47,2

teleworking could increase work engagement (through increased autonomy, reduced time pressure, and reduced role conflict) but also decrease work engagement (through increased role ambiguity, reduced feedback, and reduced support). Boell et al. (2016, p. 128) focus on the often paradoxical findings in telework research and conclude that the jury is still out on whether telework "is ultimately a 'good' or a 'bad' thing."

Peters et al. (2014) combine insights on the impact of the various facets of NWW with the insights of the job demands-resources model (JD-R model) (Demerouti et al., 2001; Bakker and Demerouti, 2007), to explain the mechanisms affecting "work-related flow." In a similar way, the JD-R model offers the theoretical framework for the effects of NWW on work engagement, emphasizing that job demands can be stressors, while job resources can be motivators. Peters et al. (2014) argue that NWW practices induce important resources at the interpersonal level[4] as well as the job level. All facets of NWW we distinguish increase worker autonomy, which is assumed to both motivate employees in their work and enable them to cope with job demand stressors (Peters et al., 2013). Therefore, our first hypothesis is as follows:

H1. All five facets of NWW are positively related to work engagement.

\section{Possible mediators}

Social interaction in the workplace. Social interaction is beneficial for organizations, as it fosters valuable resource collaboration, leading to positive work attitudes (Bakker et al., 2004). However, to use social interaction as a mediator between NWW and work engagement, NWW should also affect social interaction at work.

Peters et al. (2014) argue that NWW practices could induce important resources at the interpersonal level - such as supportive behavior of line managers and colleagues - that both motivate employees in their work and enable them to cope with job demand stressors. Various studies on NWW find that social interaction (or very similar concepts) mediates between NWW and employee-level outcome variables. De Leede and Kraijenbrink (2014), studying a Dutch insurance firm, find that social cohesion, which is related to social interaction, positively mediates the relation between NWW and self-assessed productivity of employees. Moreover, in a five-day diary study, Ten Brummelhuis et al. (2012) find that NWW positively affects effective and efficient communication and that these interactions, in turn, affect work engagement positively.

Furthermore, various studies show the relation between one or more individual facets of NWW and social interaction. The first three facets of NWW - time- and location-independent work, management of output, and free access to and use of organizational knowledge, experience, and ideas - are associated with what is known in the literature as FWDs, teleworking, or telecommuting. This literature contains numerous studies on the relation between these facets and social interaction. However, the sign of the effect is not unambiguously clear. Various studies on FWDs, telework, and telecommuting underscore the positive effects of such work designs on effective and efficient communication (e.g. Ter Hoeven and Van Zoonen, 2015; Ten Brummelhuis et al., 2012), or on the quality of the employee-supervisor relationship (e.g. Gajendran and Harrison, 2007; Golden, 2006). However, other studies find no significant relation between telecommuting and effective communication (Duxbury and Neufeld, 1999), between telecommuting and the quality of co-worker relationships (Gajendran and Harrison, 2007), or between NWW and psychosocial work characteristics, including support from colleagues and supervisors (Nijp et al., 2016). In addition, some studies show a negative relation between working outside the office and social interaction at work (Morganson et al., 2010), or between telecommuting and the quality of co-worker relationships (Golden, 2006). Finally, Halford (2005) provides numerous examples (in both positive and negative directions) of how telework changes organizational relationships and interactions. 
With regard to the fourth facet of NWW, flexibility in working relations, Branine (2003) finds that job sharers[5] mention as advantages of this flexible arrangement the transfer of expertise and knowledge as well as the mutual support and help they get from each other. Similarly, Kossek and Lee (2008) argue that reduced workload (a specific form of part-time work) improves co-worker relationships and communication.

The fifth facet of NWW, a freely accessible open workplace, is as mentioned earlier, intended to minimize physical and mental distance in the work place by stimulating encounters and cooperation among colleagues. This underscores the potentially mediating effect of social interaction on the impact of open workplaces on work engagement. However, as Kim and De Dear (2013) show, the positive impact of an open workplace on social interaction might be offset by the negative impacts from loss of privacy and noise, when it comes to overall workspace satisfaction.

Based on the above literature, we hypothesize that social interaction at work mediates the relationship between NWW facets and work engagement, without a priori formulating expectations regarding the sign of the effect:

H2. Social interaction mediates the relationship between NWW and work engagement.

\section{Transformational leadership}

Several studies show that transformational leadership is positively related to work engagement (e.g. Bakker et al., 2011; Bailey et al., 2017). As a mediator between NWW and work engagement, NWW should also affect the level of transformational leadership. Peters et al. (2014) argue that NWW practices could induce supportive behavior of line managers (associated with transformational leadership), which both motivates employees in their work and enables them to cope with job demand stressors. Various studies on NWW find that the introduction of NWW or one or more of its facets indeed leads to changes in the management style toward more transformational leadership. According to De Leede and Kraijenbrink (2014), a big challenge for managers is switching from direct supervision to managing based on worker output, which is a key consequence of NWW, since managers no longer see their employees on a daily basis. Hence, as NWW is introduced, workers' roles and behavior in organizations evolve over time[6]. With regard to the introduction of flexible working arrangements, Johnson (2004, pp. 725-726) states that: "line managers have to learn potentially new ways of thinking and doing and from them, derive new attitudes and role behavior" and that "persuading and influencing skills to ensure that staff do perform even away from their place of work [...] are not automatically inherent nor can be acquired overnight." Moreover, Daniels et al. (2000) argue that managing teleworkers requires changes in management approaches, and Peters and Den Dulk (2003) argue that this may require introduction of management by objectives. Further, Halford (2005) finds that introduction of a hybrid workspace (homeworking plus virtual working) changes management practices due to a "loss of the causal inputs derived from co-location: overhearing and overseeing" as well as because "the re-spatialisation of work and organisation challenged traditional managerial surveillance practices” (Halford, 2005, p. 29). Even when employees do work in the office, they still manage their own work, which requires management of output. This change requires transformational leadership that elevates workers' concerns for achievement (Bass, 1999).

Several studies show that transformational leadership (or one or more of its elements) mediates between NWW (or one or more of its facets) and individual-level outcomes, such as work engagement. De Leede and Kraijenbrink (2014) find that trusting leadership mediates between NWW and employee performance. Furthermore, De Leede and Heuver (2017) include several leadership competencies associated with transformational leadership (such 
PR

47,2

522

as empowerment and steering output) as the moderators in their study on NWW and organizational commitment (which is related to work engagement (Hallberg and Schaufeli, 2006)), but do not find a moderating effect. Therefore, they join Dahlstrom (2013) in suggesting that leadership may be a mediator between NWW[7] and organizational commitment. Kelley and Kelloway (2012) find that transformational leadership positively mediates the relation between remote working environments (where managers have less face-to-face interaction with their workers) and several outcomes, such as organizational commitment and job satisfaction.

Based on the above literature, we expect that transformational leadership positively mediates the relation between NWW and work engagement, as follows:

H3. Transformational leadership positively mediates the relationship between NWW and work engagement.

Figure 1 gives an overview of the hypothesized relationships between NWW facets and work engagement.

\section{Data and methodology}

For our empirical analysis, we use survey data from a representative panel of Dutch households collected by RMI (a full-service market research company)[8]. Our questionnaire (see Table AI) was sent to 5,000 panel members in June 2013. The survey resulted in 901 responses (18 percent response rate). To focus on employees without management responsibilities, we exclude 37 entrepreneurs and 161 managers from our sample, resulting in a data set of 703 employees. Further, we exclude 47 employees for whom we could not construct the fifth facet on the freely accessible open workplace, as they reported that they do not work in a building (e.g. truck, taxi, and train drivers, postal deliverers). This results in a final sample of 656 employees employed in a wide range of sectors and occupational fields.

To measure work engagement, we use the nine-statement version of the "Utrecht work engagement scale" (Schaufeli et al., 2006). The respondents were asked to rate the nine statements on a seven-point scale, ranging from "never" to "always." All items are listed in Table AI $(\alpha=0.94)$.

To measure the extent to which employees work with NWW, we developed a set of ten items that together cover the five NWW facets[9]. All items on this scale are rated on a five-point scale ranging from "not at all" to "to a very high degree." An overview of all items used to measure the five facets of NWW is presented in Table AI $(\alpha=0.86)$.

We measure respondents' judgment on two aspects of social interaction at work by three statements derived from Golden (2006) and Van Veldhoven and Meijman (1994). The first statement measures the pleasantness of working with their colleagues ("I find working with my colleagues pleasant"). The other two statements measure the speed with which employees receive help from their colleagues and managers when facing problems ("When facing problems I quickly receive help from colleagues" and "When facing problems

Figure 1.

Overview of our hypothesized relationships between NWW facets and work engagement

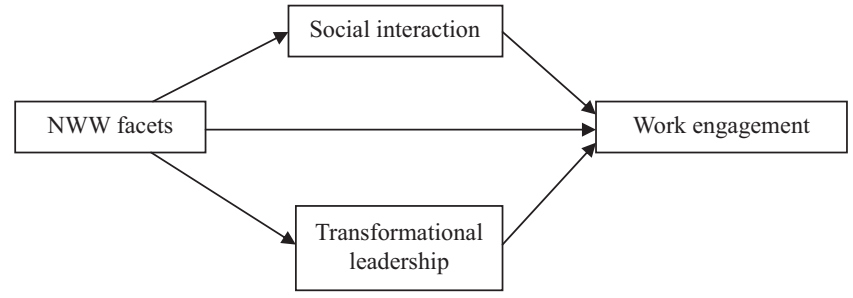


I quickly receive help from my manager"). All statements are rated on a five-point scale, ranging from "not at all" to "to a very high degree" $(\alpha=0.78)$.

Transformational leadership is measured by both the emotional quotient and the spiritual quotient, using a set of nine items derived from Bass (1991) and Robbins and Judge (2007). Managers who use practices included in the emotional quotient focus on asking questions, and display increased awareness of others. Examples of statements we use here are: "My supervisor provides guidance when I need it," and "My supervisor considers the individual." Transformational leadership based on a spiritual quotient provides inspirational motivation to employees. Example statements for transformational leadership based on a spiritual quotient include: "My supervisor inspires and motivates employees," and "My supervisor gives a clear image of his strategic vision." All these statements are rated on a five-point scale, ranging from "not at all" to "to a very high degree." A full list of statements used is presented in Table AI $(\alpha=0.95)$.

Table I shows the Cronbach's $\alpha$ coefficient for the various facets of NWW and the correlations among NWW as an aggregate variable including all ten items, the separate facets of NWW, and the two possible mediators. All Cronbach's $\alpha$ coefficients show that the variables we distinguish are internally consistent[10]. Moreover, we perform factor analyses based on a polychoric correlation matrix on the latent constructs of work engagement, social interaction, and transformational leadership. All three variables show only one eigenvalue above 1 and adequate to strong factor loadings for all items[11]. We standardize these variables to a mean of 0 and standard deviation of 1 .

\section{Results}

We first test a multiple mediation model in which we take the aggregate NWW variable as the independent variable. We apply the Preacher and Hayes' (2008) bootstrap method for multiple mediation and control variables to overcome the limitations of the causal steps approach introduced by Baron and Kenny (1986). One of the limitations of the causal steps approach is that the existence of indirect effects is inferred and not tested (Hayes, 2009). Preacher and Hayes' (2008) bootstrap method enables us to test the specific indirect effects $\left(a_{\mathrm{i}} b_{\mathrm{i}}\right)$, the total indirect effect $\left(\Sigma\left(a_{\mathrm{i}} b_{\mathrm{i}}\right)\right)$, and the total effect $(c)$. It uses OLS regressions to estimate the coefficients of all direct relations $\left(a_{\mathrm{i}}, b_{\mathrm{i}}\right.$, and $\left.c^{\prime}\right)$, followed by bootstrapping to compute the confidence intervals that determine the significance of the indirect and total effects. We estimate the model controlling for age, industry sector, and occupational field, which are known to relate to work engagement (e.g. Schaufeli, 2012). Figure 2 summarizes our findings[12]. This figure shows a significant total effect of NWW on work engagement $(\beta=0.41)$. Moreover, NWW has significant effects on the two mediators social interaction

\begin{tabular}{lccccccccc}
\hline & 1 & 2 & 3 & 4 & 5 & 6 & 7 & 8 & 9 \\
\hline (1) Work engagement & $(0.94)$ & & & & & & & \\
(2) New ways of working (aggregate) & 0.33 & $(0.86)$ & & & & & & \\
(3) NWW Facet 1: Anytime, anywhere & 0.19 & 0.71 & $(0.78)$ & & & & & \\
(4) NWW Facet 2: Management of output & 0.30 & 0.66 & 0.55 & & & & & \\
(5) NWW Facet 3: Access to & & & & & & & & \\
$\quad$ organizational knowledge & 0.29 & 0.85 & 0.35 & 0.44 & $(0.77)$ & & & \\
(6) NWW Facet 4: Flexibility in working relations & 0.20 & 0.73 & 0.71 & 0.50 & 0.43 & & & & \\
(7) NWW Facet 5: Freely accessible open workplace & 0.25 & 0.70 & 0.24 & 0.32 & 0.60 & 0.29 & $(0.78)$ & \\
(8) Social interaction & 0.44 & 0.46 & 0.17 & 0.22 & 0.51 & 0.24 & 0.40 & $(0.78)$ \\
(9) Transformational leadership & 0.45 & 0.45 & 0.30 & 0.28 & 0.37 & 0.31 & 0.39 & 0.54 & $(0.95)$
\end{tabular}

Notes: $n=656$. Cronbach's $\alpha$ coefficients are shown in the diagonal. All correlations are significant at $p<0.001$

New ways of working

Table I. Internal consistencies and correlations between the variables 
PR

47,2

524

Figure 2.

Multiple mediation model of direct and indirect effects of NWW on work engagement
( $\beta=0.52)$ and transformational leadership $(\beta=0.50)$. In turn, social interaction $(\beta=0.23)$ and transformational leadership $(\beta=0.26)$ have significant direct effects on work engagement. After accounting for these significant indirect effects via social interaction $(\beta=0.12)$ and transformational leadership $(\beta=0.13)$, there remains a positive and highly significant direct effect of NWW on work engagement $(\beta=0.16)[13]$. However, partial mediation is substantial, as the direct effect $(\beta=0.16)$ is smaller than the total indirect effect $(\beta=0.25)$. This means that the indirect effect accounts for 61 percent of the total effect.

Of our control variables age, sector, and occupation, age shows a significant positive relation to work engagement, and the respondents who work in economic/administrative jobs and law enforcement and public safety jobs report significantly lower engagement compared to those in other occupations. There are no significant effects from our sector control variable. Our total model is highly significant $(p<0.001)$ and explains 34 percent of the variance in work engagement.

Second, we test a multiple mediation model that includes the five separate facets of NWW as independent variables, also using the Preacher and Hayes' (2008) bootstrap method for multiple mediation and control variables and using the same controls as before. Figure 3 summarizes the findings of this analysis[14]. The NWW facets management of output $(\beta=0.17)$, access to organizational knowledge $(\beta=0.16)$, and freely accessible open workplace $(\beta=0.13)$ all have a significant total effect on work engagement. However, this does not hold for the facets time- and location-independent work and flexibility in working relations. These results provide partial support for $H 1$, which predicts a positive relationship for all five facets. Next, we see that there are significant relations between the facets access to organizational knowledge and freely accessible open workplace and the mediators social interaction ( $\beta=0.42$ and $\beta=0.16$, respectively) and transformational leadership $(\beta=0.15$ and $\beta=0.25$, respectively). Furthermore, the facet time- and location-independent work $(\beta=0.16)$ has a significant relation with the mediator transformational leadership. Finally, the two mediating variables social interaction $(\beta=0.25)$ and transformational leadership $(\beta=0.26)$ are both significantly related to work engagement.

The specific indirect effects on work engagement that run via the two mediators are shown in parentheses, and the direct effects after accounting for mediation are shown in brackets. After accounting for mediation, the direct effects of access to organizational knowledge $(\beta=0.01)$ and freely accessible open workplace $(\beta=0.03)$ on work engagement are not significant. The impact of both facets is thus fully mediated by social interaction and transformational leadership. The indirect effect of the facet access to organizational knowledge on work engagement runs mainly via social interaction $(\beta=0.11)$, which more strongly mediates this relation than transformational leadership $(\beta=0.04)$. The indirect effect of the facet freely accessible open workplace runs slightly more strongly via transformational leadership $(\beta=0.06)$ than via social interaction $(\beta=0.04)$.

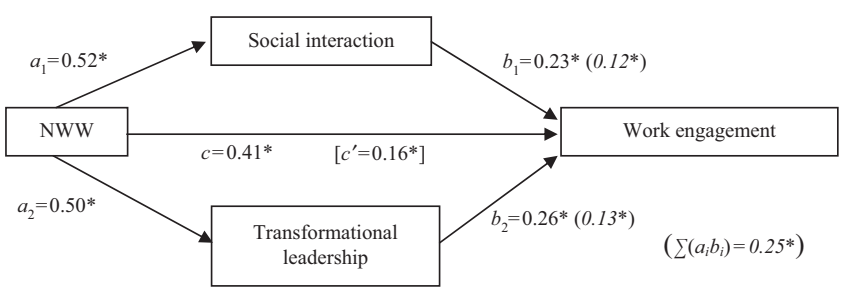

Notes: Indirect effects $\left(a_{i} b_{i}\right)$ and total indirect effect $\left(\sum\left(a_{i} b_{i}\right)\right)$ are shown in italics in parentheses. Direct effect of NWW accounting for mediation is shown in brackets. Total effect $c=\sum\left(a_{i}^{*} b_{i}\right)+c^{\prime} .{ }^{*} p<0.01$ 


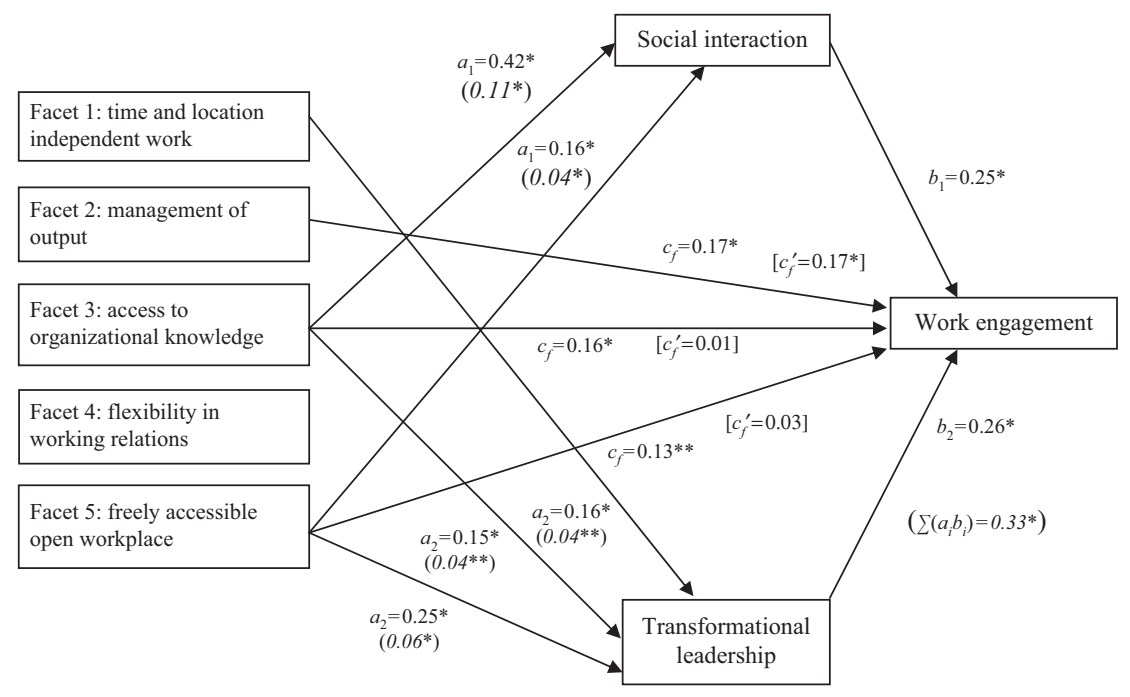

Notes: Indirect effects $\left(a_{i} b_{i}\right)$ and total indirect effect $\left(\sum\left(a_{i} b_{i}\right)\right)$ are shown in italics in parentheses. Direct effects of NWW facets accounting for mediation are shown in brackets. We only show significant relations. Total effect per facet " $f$ " is $c_{f}=\sum\left(a_{i, f}{ }^{*} b_{i}\right)+c_{f}^{\prime} .{ }^{*} p<0.01$; $* * p<0.05$

However, the direct effect of the NWW facet management of output is not mediated by social interaction or transformational leadership and is highly significant and positively related to work engagement after accounting for both mediating effects. These results partly support $H 2$ and $H 3$, which predict a mediating role for social interaction and transformational leadership, respectively between all NWW facets and work engagement. The total model is again highly significant $(p<0.001)$ and explains 34 percent of the variance in work engagement. The effects of our control variables are the same as found in our first model with NWW as one aggregate variable.

\section{Discussion}

We find that, controlling for age, industry sector, and occupational field, NWW as an aggregate concept is positively related to work engagement of employees in The Netherlands. This relationship is partially mediated by both social interaction and transformational leadership. Our subsequent analysis, which focuses on five separate facets of NWW, reveals that three facets of NWW positively affect work engagement: management of output, access to organizational knowledge, and freely accessible open workplace, while the facets time- and location-independent work and flexibility in working relations are not significantly related to work engagement. The positive relation between a freely accessible open workplace and work engagement appears to be fully mediated by social interaction in the workplace and transformational leadership. The effect of access to organizational knowledge on work engagement is also mediated largely by social interaction, and somewhat less by transformational leadership. Our analysis further shows that the NWW facet management of output, which refers to worker autonomy, is not mediated by social interaction or transformational leadership. As such, it is the only facet that directly affects work engagement.
New ways of working

525

Figure 3.

Multiple mediation model of direct and indirect effects of individual facets of

NWW on work engagement 
PR

47,2

\section{Theoretical contributions}

We extend the emerging literature on the effects of NWW on work engagement in several ways. We extend the Dutch study of Peters et al. (2013), who investigate only direct effects, by including social interaction and transformational leadership as mediators. Our finding that the indirect effects of NWW on work engagement via social interaction and transformational leadership account for 61 percent of the total effect emphasizes the importance of social interaction and transformational leadership as conduits and the importance of including these mediators when analyzing effects of NWW.

We also extend the work of Ten Brummelhuis et al. (2012), which uses data from a single firm and treat NWW solely as an aggregate construct, as we use a representative sample of the Dutch working population comprising 12 occupational fields across all sectors of the economy and distinguish five separate facets of NWW. We show that the positive effect of NWW on work engagement can be generalized beyond the level of the single firm.

In addition, including social interaction and transformational leadership as mediators while also distinguishing NWW in five separate facets, allows us to disentangle which NWW facets are responsible for the positive effect on work engagement, and which facets play no role or merely an indirect one. Our finding that the facets access to organizational knowledge and freely accessible open workplace are both mediated by social interaction and transformational leadership suggests that these facets in themselves do not promote work engagement. Rather, it is an indirect process: a freely accessible open workplace and access to organizational knowledge stimulate social interaction and transformational leadership, which both foster work engagement.

Our study also contributes to the thin literature on employee outcomes of NWW in general, such as De Leede and Kraijenbrink (2014), who find positive effects of NWW on employee performance in a Dutch insurance company, Peters et al. (2014), who find that NWW can have positive effects on work-related flow, and De Leede and Heuver (2017), who find a positive relation between NWW and both productivity and organizational commitment.

\section{Practical implications}

Our finding that management of output is the only NWW facet that directly impacts employee work engagement, without being mediated, underscores that providing workers with more autonomy is a very effective way to increase their engagement (Schaufeli, 2012; De Spiegelaere et al., 2016). This finding is important for HR decision makers, as it shows that it is not necessary to implement a full set of NWW facets to increase employee work engagement. When organizations consider implementing a more comprehensive set of NWW facets, including creation of a freely accessible open workplace and access to organizational knowledge, our results show that this increases work engagement only if the organization also fosters transformational leadership and social interaction in the workplace. Both fully mediate the effects of a freely accessible open workplace and access to organizational knowledge on employee work engagement, which suggests that transformational leadership and social interaction are necessary conduits via which a freely accessible open workplace and access to organizational knowledge affect employee work engagement.

On one end of the spectrum, there may be organizations where line managers are not able or willing to move toward a more transformational leadership style. Such organizations will benefit little from implementing a more comprehensive set of NWW facets, and only when increasing employees' ability to manage their own work. On the other end of the spectrum, there may be organizations that foster social interaction in the workplace and have line managers who are both able and willing to adopt a more transformational leadership style. In such organizations, implementing a more comprehensive set of NWW facets will have a 
larger impact on work engagement than implementing only management of output practices, since through the mediating effects of increased transformational leadership and social interaction, freely accessible open workplaces and access to organizational knowledge further improve work engagement. These implications are in line with those from the related telework literature, which finds that management attitudes are the key to successful adoption of telework (Maruyama and Tietze, 2012). Moreover, in organizations where management style is more transactional, based on strong hierarchies, with a lack of trust in employees working out-of-sight, introduction of telework should be complemented with HR practices to "build a culture of trust through empowerment, delegation and results-based performance management systems" (Martínez-Sánchez et al., 2007, p. 219).

Since most changes to organizations' working methods and habits, such as a move from a traditional way of working to NWW, are costly, time-consuming, and may require substantial periods of adjustment, understanding the managerial abilities, and preferences of line managers is important for decision makers who consider implementing NWW. This is also recognized in the context of telework by Watad and Will (2003), who conclude that middle management is extremely important, because the adoption of telework affects their positions. Similarly, Peters and Heusinkveld (2010) conclude that paying attention to manager subcultures is important in the context of alternative work-life arrangements. Thus, to maximize the positive impact of NWW on work engagement, while keeping the cost of introducing NWW to a minimum, firms should take account of the abilities and preferences of their line managers. Depending on these, a more limited or comprehensive set of NWW facets may be most efficient at promoting work engagement.

\section{Limitations and future research}

Our use of cross-sectional data does not allow us to identify causal relationships. Moreover, cultural differences between working populations in different countries may restrict the external validity of our findings, which derive from a data set on the Dutch working population. Future research should therefore attempt to analyze the effects of NWW in a longitudinal and international setting, taking account of different cultural dimensions. Furthermore, we could not distinguish between employees already used to working with particular NWW facets for several years and those who just started to work with particular facets of NWW. Future research should therefore take account of the different stages of implementation of the NWW facets.

\section{Notes}

1. These facets are constructed from various underlying items (see Table AI).

2. De Souza e Silva (2006) takes a slightly different viewpoint, arguing that there is no longer a distinction between digital and physical space. Therefore, it is not necessary to refurbish offices into freely accessible open workplaces, since IT solutions already foster encounters between colleagues.

3. See, for instance, Ter Hoeven and Van Zoonen (2015).

4. We discuss this below where we formulate our hypotheses on social interaction in the workplace and transformational leadership as mediators.

5. A flexible working relation whereby two workers are responsible for sharing one full-time job.

6. See Avolio et al. (2014) for a literature survey on how changes such as the rise in advanced information technology and the concomitant new ways of organizing work transform leadership.

7. Dahlstrom's study focuses on telecommuting.

8. See http://www.rminteractive.nl/panels/
New ways of working 
PR

9. The items to measure time- and location-independent work (Facet 1) and management of output (Facet 2) stem from the Maastricht Autonomy Questionnaire (MAQ) (De Jonge, Landeweerd, and Van Breukelen, 1994). The items to measure access to organizational knowledge (Facet 3) and flexibility in working relations (Facet 4) were developed by the authors to match the definitions of these facets by Baane et al. (2010). The items to measure freely accessible open workplace (Facet 5) were developed by the authors to match the facet description of Halford (2005) and Graham (2004).

10. Facets 2 (management of output) and 4 (flexibility in working relations) are single-item facets. Applying the criteria developed by Fuchs and Diamantopoulos (2009), we conclude that using a single item for these facets is justifiable, as both facets are relatively concrete and unidimensional and our sampled population is very diverse (12 different occupational fields across all sectors).

11. On work engagement, all factor loadings are between 0.81 and 0.89 , except for one, which is at a still adequate 0.65 . On social interaction, factor loadings are $0.67,0.77$, and 0.87 , and on transformational leadership they are between 0.75 and 0.92 .

12. We standardized all variables after dropping observations that are missing on variables contained in the analysis.

13. Table AII presents the bootstrap results we used to determine the significance of the indirect effects. It shows the coefficients of the indirect effects as well as the bootstrapped standard errors, $Z$-values, and confidence intervals. As zero is not included in the confidence intervals of either mediator, both indirect effects are significant. We rounded the numbers in the main text and figures to two decimals.

14. We also tested for mediation by conducting several OLS regressions, performing all the steps outlined by Baron and Kenny (1986) to test for mediation. This yields the same conclusions. Moreover, we also performed a structural equation modeling analysis including the five separate facets of NWW, social interaction, transformation leadership, work engagement and age (we here excluded the sector and occupation controls as these categorical variables cannot be meaningfully included in the SEM analysis), which also yields the same conclusions.

\section{References}

Avolio, B.J., Sosik, J.J., Kahai, S.S. and Baker, B. (2014), "E-leadership: re-examining transformations in leadership source and transmission”, The Leadership Quarterly, Vol. 25 No. 1, pp. 105-131.

Baane, R., Houtkamp, P. and Knotter, M. (2010), Het Nieuwe Werken ontrafeld - Over Bricks, Bytes en Behavior, Koninklijke Van Gorcum, Assen.

Bailey, C., Madden, A., Alfes, K. and Fletcher, L. (2017), "The meaning, antecedents and outcomes of employee engagement: a narrative synthesis", International Journal of Management Reviews, Vol. 19 No. 1, pp. 31-53.

Bakker, A.B. and Bal, M.P. (2010), "Weekly work engagement and performance: a study among starting teachers", Journal of Occupational and Organizational Psychology, Vol. 83 No. 1, pp. 189-206.

Bakker, A.B. and Demerouti, E. (2007), "The job demands-resources model: state of the art”, Journal of Managerial Psychology, Vol. 22 No. 3, pp. 309-328.

Bakker, A.B., Albrecht, S.L. and Leiter, M.P. (2011), "Work engagement: further reflections on the state of play”, European Journal of Work and Organizational Psychology, Vol. 20 No. 1, pp. 74-88.

Bakker, A.B., Demerouti, E. and Verbeke, W. (2004), "Using the job demands-resources model to predict burnout and performance", Human Resource Management, Vol. 43 No. 1, pp. 83-104.

Bakker, A.B., Schaufeli, W.B., Leiter, M.P. and Taris, T.W. (2008), "Work engagement: an emerging concept in occupational health psychology", Work \& Stress, Vol. 22 No. 3, pp. 187-200.

Bal, P.M. and De Lange, A.H. (2015), "From flexibility human resource management to employee engagement and perceived job performance across the lifespan: a multisample study", Journal of Occupational and Organizational Psychology, Vol. 88 No. 1, pp. 126-154. 
Baron, R.M. and Kenny, D.A. (1986), "The moderator-mediator variable distinction in social psychological research: conceptual, strategic, and statistical considerations", Journal of Personality and Social Psychology, Vol. 51 No. 6, pp. 1173-1182.

Bass, B.M. (1991), "From transactional to transformational leadership: learning to share the vision", Organizational Dynamics, Vol. 18 No. 3, pp. 19-31.

Bass, B.M. (1999), "Two decades of research and development in transformational leadership", European Journal of Work and Organizational Psychology, Vol. 8 No. 1, pp. 9-32.

Boell, S.K., Cecez-Kecmanovic, D. and Campbell, J. (2016), "Telework paradoxes and practices: the importance of the nature of work", New Technology, Work and Employment, Vol. 31 No. 2, pp. 114-131.

Branine, M. (2003), "Part-time work and jobsharing in health care: is the NHS a family-friendly employer?", Journal of Health Organization and Management, Vol. 17 No. 1, pp. 53-68.

Dahlstrom, T.R. (2013), "Telecommuting and leadership style", Public Personnel Management, Vol. 42 No. 3, pp. 438-451.

Daniels, K., Lamond, D.A. and Standen, P. (2000), Managing Telework. Perspectives from Human Resource Management and Work Psychology, Thomson Learning, London.

De Jonge, J., Landeweerd, J.A. and Van Breukelen, G.J.P. (1994), "De Maastrichtse autonomielijst: achtergrond, constructie en validering (The Mastricht autonomy questionnaire: background, construction and validation)", Gedrag en Organisatie, Vol. 7 No. 1, pp. 27-41.

De Leede, J. and Heuver, P. (2017), "New ways of working and leadership: an empirical study in the service industry", in De Leede, J. (Ed.), New Ways of Working Practices: Antecedents and Outcomes, Emerald Group Publishing Limited, Bingley, pp. 49-71.

De Leede, J. and Kraijenbrink, J. (2014), "The mediating role of trust and social cohesion in the effects of new ways of working: a Dutch case study", in Bondarouk, T. and Olivas-Luján, M.R. (Eds), Human Resource Management, Social Innovation and Technology, Advanced Series in Management, Emerald Group Publishing Limited, Bingley, Vol. 14, pp. 3-20.

De Souza e Silva, A. (2006), "From cyber to hybrid mobile technologies as interfaces of hybrid spaces", Space and Culture, Vol. 9 No. 3, pp. 261-278.

De Spiegelaere, S., Van Gyes, G. and Van Hootegem, G. (2016), "Not all autonomy is the same. Different dimensions of job autonomy and their relation to work engagement \& innovative work behavior", Human Factors and Ergonomics in Manufacturing \& Service Industries, Vol. 26 No. 4, pp. 515-527.

Demerouti, E., Bakker, A.B., Nachreiner, F. and Schaufeli, W.B. (2001), "The job demands- resources model of burnout", Journal of Applied Psychology, Vol. 86 No. 3, pp. 499-512.

Duxbury, L. and Neufeld, D. (1999), "An empirical evaluation of the impacts of telecommuting on intra-organizational communication”, Journal of Engineering and Technology Management, Vol. 16 No. 1, pp. 1-28.

Fuchs, C. and Diamantopoulos, A. (2009), "Using single-item measures for construct measurement in management research: conceptual issues and application guidelines", Die Betriebswirtschaft, Vol. 69 No. 2, pp. 195-210.

Gajendran, R.S. and Harrison, D.A. (2007), "The good, the bad, and the unknown about telecommuting: meta-analysis of psychological mediators and individual consequences", Journal of Applied Psychology, Vol. 92 No. 6, pp. 1524-1541.

Golden, T.D. (2006), "The role of relationships in understanding telecommuter satisfaction”, Journal of Organizational Behavior, Vol. 27 No. 3, pp. 319-340.

Graham, S. (2004), "Beyond the 'dazzling light': from dreams of transcendence to the 'remediation' of urban life", New Media and Society, Vol. 6 No. 1, pp. 16-25.

Halford, S. (2005), "Hybrid workspace: re-spatialisations of work, organisation and management", New Technology, Work and Employment, Vol. 20 No. 1, pp. 19-33. 
PR

47,2

Hallberg, U.E. and Schaufeli, W.B. (2006), “'Same same’ but different? Can work engagement be discriminated from job involvement and organizational commitment?”, European Psychologist, Vol. 11 No. 2, pp. 119-127.

Hayes, A.F. (2009), "Beyond Baron and Kenny: statistical mediation analysis in the new millennium", Communication monographs, Vol. 76 No. 4, pp. 408-420.

Johnson, J. (2004), "Flexible working: changing the manager's role", Management Decision, Vol. 42 No. 6, pp. 721-737.

Kelley, E. and Kelloway, E.K. (2012), “Context matters: testing a model of remote leadership”, Journal of Leadership \& Organizational Studies, Vol. 19 No. 4, pp. 437-449.

Kim, J. and de Dear, R. (2013), "Workspace satisfaction: the privacy-communication trade-off in open-plan offices", Journal of Environmental Psychology, Vol. 36, pp. 18-26.

Kossek, E.E. and Lee, M.D. (2008), "Implementing a reduced-workload arrangement to retain high talent: a case study", The Psychologist-Manager Journal, Vol. 11 No. 1, pp. 49-64.

Maden, C. (2015), "Linking high involvement human resource practices to employee proactivity: the role of work engagement and learning goal orientation", Personnel Review, Vol. 44 No. 5, pp. 720-738.

Martínez-Sánchez, A., Pérez-Pérez, M., De-Luis-Carnicer, P. and Vela-Jiménez, M.J. (2007), "Telework, human resource flexibility and firm performance", New Technology, Work and Employment, Vol. 22 No. 3, pp. 208-223.

Maruyama, T. and Tietze, S. (2012), "From anxiety to assurance: concerns and outcomes of telework", Personnel Review, Vol. 41 No. 4, pp. 450-469.

Moll, F. and de Leede, J. (2016), "Fostering innovation: the influence of new ways of working on innovative work behavior", in de Leede, J. (Ed.), New Ways of Working Practices: Antecedents and Outcomes, Emerald Group Publishing Limited, Bingley, pp. 95-143.

Morganson, V.J., Major, D.A., Oborn, K.L., Verive, J.M. and Heelan, M.P. (2010), “Comparing telework locations and traditional work arrangements: differences in work-life balance support, employee satisfaction, and inclusion”, Journal of Managerial Psychology, Vol. 25 No. 6, pp. 578-595.

Mura, M., Lettieri, E., Spiller, N. and Radaelli, G. (2012), "Intellectual capital and innovative work behaviour: opening the black box", International Journal of Engineering Business Management, Vol. 4 No. 39, pp. 1-10.

Nijp, H.H., Beckers, D.G., van de Voorde, K., Geurts, S.A. and Kompier, M.A. (2016), "Effects of new ways of working on work hours and work location, health and job-related outcomes", Chronobiology international, Vol. 33 No. 6, pp. 604-618.

Peters, P. and den Dulk, L. (2003), "Cross-cultural differences in managers' support for home- based telework a theoretical elaboration", International Journal of Cross Cultural Management, Vol. 3 No. 3, pp. 329-346.

Peters, P. and Heusinkveld, S. (2010), "Institutional explanations for managers' attitudes towards telehomeworking”, Human Relations, Vol. 63 No. 1, pp. 107-135.

Peters, P., Kraan, K. and van Echtelt, P. (2013), "Floreren onder condities van Het Nieuwe Werken: minder burnout, meer toewijding?", Tijdschrift voor Arbeidsvraagstukken, Vol. 3 No. 29, pp. 304-321.

Peters, P., Poutsma, E., Van der Heijden, B.I., Bakker, A.B. and Bruijn, T.D. (2014), "Enjoying new ways to work: an HRM-process approach to study flow", Human Resource Management, Vol. 53 No. 2, pp. 271-290.

Preacher, K.J. and Hayes, A.F. (2008), "Asymptotic and resampling strategies for assessing and comparing indirect effects in multiple mediator models", Behavior Research Methods, Vol. 40 No. 3, pp. 879-891.

Rana, S., Ardichvili, A. and Tkachenko, O. (2014), "A theoretical model of the antecedents and outcomes of employee engagement: Dubin's method”, Journal of Workplace Learning, Vol. 26 Nos 3/4, pp. 249-266. 
Robbins, S.P. and Judge, T. (2007), Organizational Behavior, Pearson/Prentice Hall, Upper Saddle River, NJ.

Saks, A.M. (2006), "Antecedents and consequences of work engagement", Journal of Managerial Psychology, Vol. 21 No. 7, pp. 600-619.

Sardeshmukh, S.R., Sharma, D. and Golden, T.D. (2012), "Impact of telework on exhaustion and job engagement: a job demands and job resources model", New Technology, Work and Employment, Vol. 27 No. 3, pp. 193-207.

Schaufeli, W. (2012), "Work engagement: what do we know and where do we go?", Romanian Journal of Applied Psychology, Vol. 14 No. 1, pp. 3-10.

Schaufeli, W.B., Bakker, A.B. and Salanova, M. (2006), "The measurement of work engagement with a short questionnaire: a cross-national study”, Educational and Psychological Measurement, Vol. 66 No. 4, pp. 701-716.

Schaufeli, W.B., Salanova, M., Gonzalez-Roma, V. and Bakker, A.B. (2002), "The measurement of engagement and burnout: a two sample confirmatory factor analytic approach", Journal of Happiness Studies, Vol. 3 No. 1, pp. 71-91.

Ten Brummelhuis, L.L., Bakker, A.B., Hetland, J. and Keulemans, L. (2012), "Do new ways of working foster work engagement?”, Psicothema, Vol. 24 No. 1, pp. 113-120.

Ter Hoeven, C.L. and Van Zoonen, W. (2015), "Flexible work designs and employee well-being: examining the effects of resources and demands", New Technology, Work and Employment, Vol. 30 No. 3, pp. 237-255.

Thompson, C.A. and Prottas, D.J. (2006), "Relationships among organizational family support, job autonomy, perceived control, and employee well-being", Journal of Occupational Health Psychology, Vol. 11 No. 1, pp. 100-118.

Veldhoven, M.J.P.M. and Meijman, T.F. (1994), "Het meten van psychosociale arbeidsbelasting met een vragenlijst: de vragenlijst beleving en beoordeling van de arbeid (VBBA) (The measurement of psychosocial strain at work: the questionnaire experience and evaluation of work)", NIA, Amsterdam.

Watad, M.M. and Will, P.C. (2003), “Telecommuting and organizational change: a middle-managers' perspective", Business Process Management Journal, Vol. 9 No. 4, pp. 459-472.

(The Appendix follows overleaf.) 


Variable Statements

\section{Work engagement}

New ways of working Facet 1: Time- and locationindependent work

Facet 2: Management of output

Facet 3: Access to organizational knowledge
At my work, I feel bursting with energy (1) Never-(7) Always At my job, I feel strong and vigorous I am enthusiastic about my job My job inspires me

(1) Never-(7) Always

(1) Never-(7) Always

(1) Never-(7) Always When I get up in the morning, I feel like (1) Never-(7) Always going to work

I feel happy when I am working $\quad$ (1) Never-(7) Always intensely

I am proud on the work that I do

I am immersed in my work

I get carried away when I'm working

(1) Never-(7) Always

(1) Never-(7) Always

(1) Never-(7) Always

I am able to set my own working hours

I am able to determine where I work I am able to determine the way I work

(1) Not at all-(5) To a high degree

(1) Not at all-(5) To a high degree (1) Not at all-(5) To a high degree

I can access all necessary information on my computer, smartphone, and/or tablet I am able to reach colleagues within the team quickly

I am able to reach managers quickly (1) Not at all-(5) To a high degree

I am able to reach colleagues outside the (1) Not at all-(5) To a high degree team quickly

Facet 4: Flexibility in working I have the ability to adapt my working relations scheme to my phase of life and ambitions.

Facet 5: Freely accessible open The building is arranged so that workplace colleagues are easily accessible The building is arranged so that managers are easily accessible

(1) Not at all-(5) To a high degree

(1) Not at all-(5) To a high degree

(1) Not at all-(5) To a high degree

(1) Not at all-(5) To a high degree

(1) Not at all-(5) To a high degree

\section{Social interaction}

I find working with my colleagues pleasant

When facing problems I quickly receive (1) Not at all-(5) To a high degree help from colleagues

When facing problems I quickly receive (1) Not at all-(5) To a high degree help from my manager

\section{Transformational leadership}

My supervisor gives a clear image of his (1) Not at all-(5) To a high degree strategic vision

My supervisor exhibits desirable

behavior within the organization

My supervisor acts as a role model within (1) Not at all-(5) To a high degree the organization

My supervisor provides guidance when I (1) Not at all-(5) To a high degree need it
Table AI.

Questionnaire 


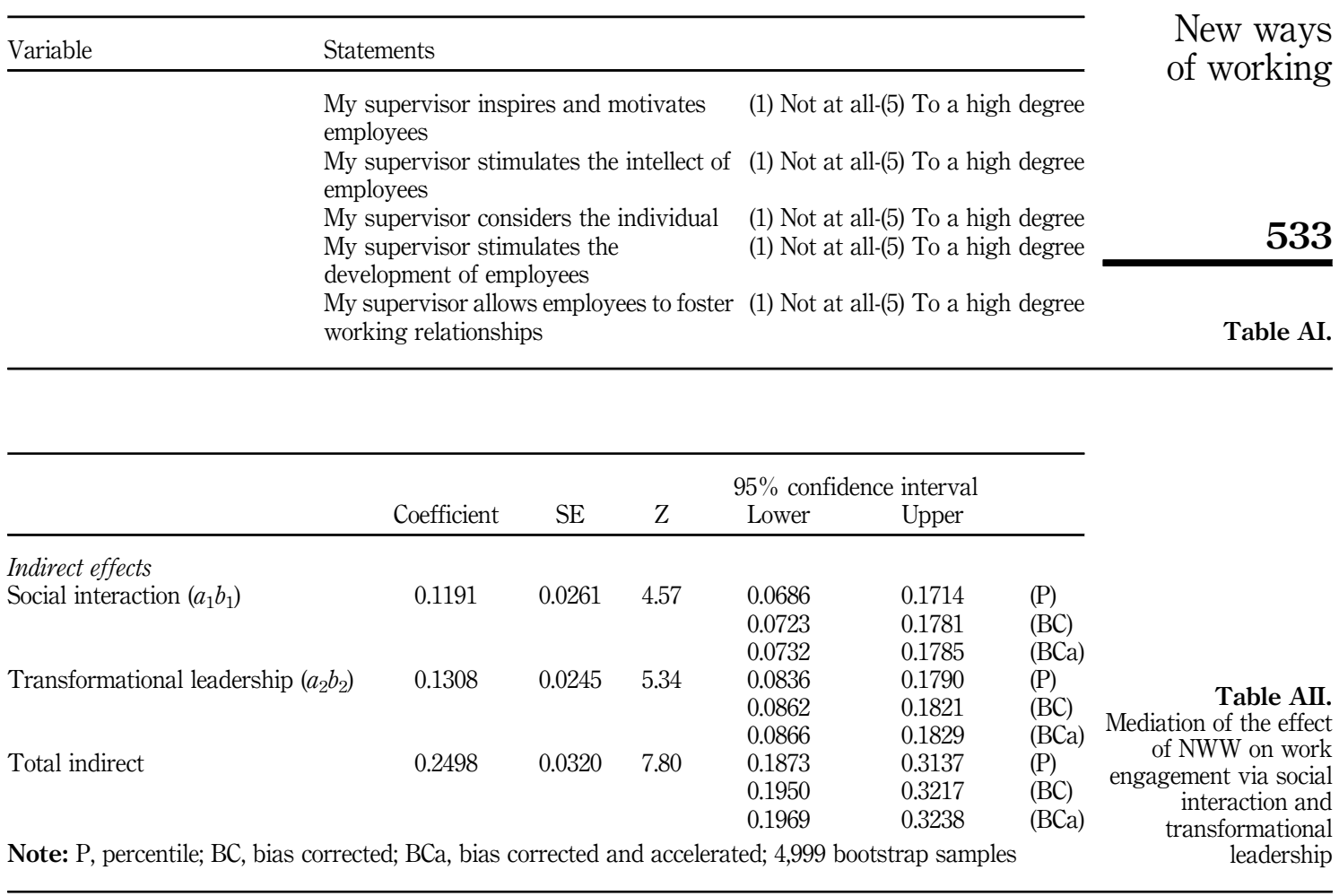




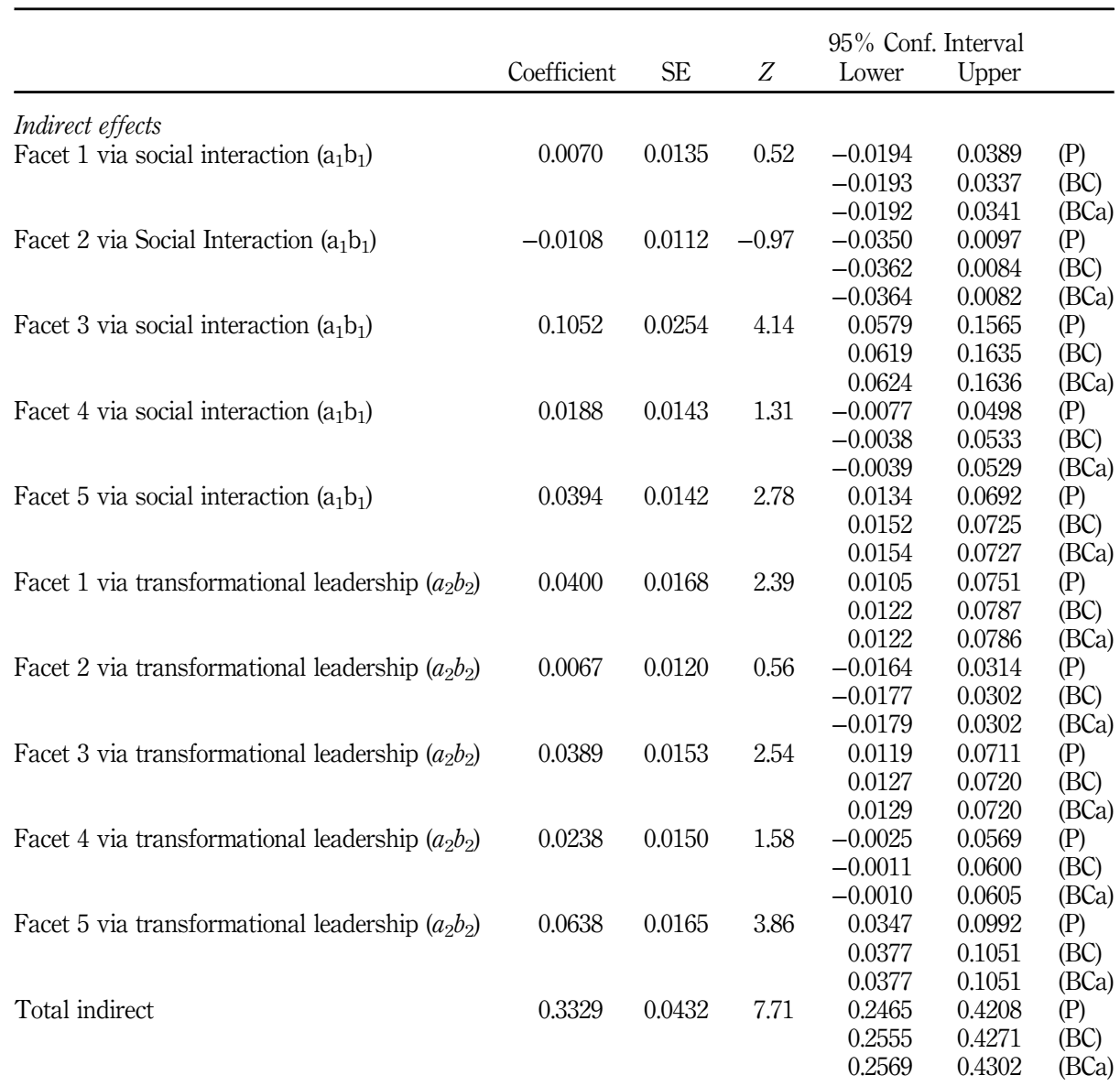

Table AIII.

Mediation of the effect of the individual NWW facets on work engagement via social interaction and transformational leadership

Notes: P, percentile; BC, bias corrected; BCa, bias corrected and accelerated; 4,999 bootstrap samples

\section{Corresponding author}

Ruud Gerards can be contacted at: r.gerards@maastrichtuniversity.nl

For instructions on how to order reprints of this article, please visit our website: 